\title{
EFEKTIVITAS MODEL PROBLEM BASED LEARNING BERBANTUAN MEDIA AUDIO VISUAL DITINJAU DARI \\ HASIL BELAJAR IPA SISWA KELAS 5 SDN 1 GADU SAMBONG - BLORA SEMESTER 2 \\ TAHUN 2014/2015
}

\author{
Adhini Virgiana dan Wasitohadi \\ adi_wasito02@yahoo.co.id \\ Pendidikan Guru Sekolah Dasar - FKIP - UKSW
}

\begin{abstract}
ABSTRAK
Tujuan dari penelitian ini adalah untuk mengetahui perbedaan tingkat hasil belajar antara model problem based learning berbantuan media audio visual dengan model pembelajaran think pair share berbantuan media visual pada pembelajaran IPA siswa kelas 5 SDN 1 Gadu Sambong Kabupaten Blora semester 2 tahun pelajaran 2014/2015. Penelitian ini merupakan penelitian quasi experiment dengan nonequivalent control group design. Subjek penelitian dalam penelitian ini adalah siswa kelas 5 SDN 1 Gadu dan siswa kelas 5 SDN 2 Gagakan. Teknik pengumpulan data dalam penelitian adalah tes dan observasi. Teknik analisis data yang digunakan adalah statistik deskriptif, statistik parametrik, dan uji t dengan independent sample t-tes pada taraf signifikansi 5\% $(\alpha=0,05)$. Berdasarkan hasil penelitian dan pembahasan, maka dapat disimpulkan bahwa terdapat perbedaan tingkat efektivitas antara model problem based learning berbantu media audio visual dengan model pembelajaran think pair share berbantu media visual terhadap hasil belajar IPA siswa kelas 5 SDN 1 Gadu Kecamatan Sambong Kabupaten Blora semester 2 tahun 2014/2015. Terbukti hal ini ditunjukkan oleh hasil uji t-test sebesar 3,603 > 1,999 dan signifikansi sebesar 0,001<0,05. Perbedaan rata-rata kelas eksperimen > rata-rata kelas kontrol yaitu 87,0588 > 80,2000.
\end{abstract}

Kata kunci: Pembelajaran IPA, Model Problem Based Learning, Media Audio Visual, Hasil Belajar

\section{PENDAHULUAN}

Menurut Undang-Undang Sisdiknas No. 20 Tahun 2003 pasal 1 tentang sistem pendidikan nasional disebutkan bahwa pendidikan adalah usaha sadar dan terencana untuk mewujudkan suasana belajar dan proses pembelajaran agar siswa secara aktif mengembangkan potensi diri, kepribadian, kecerdasan, akhlak mulia, serta ketrampilan yang diperlukan dirinya, masyarakat, bangsa, dan mengembangkan sikap dan kemampuan serta memberikan pengetahuan dan ketrampilan dasar yang diperlukan untuk hidup dalam masyarakat serta mempersiapkan siswa mengikuti pendidikan menengah. 
Permendiknas No. 41 Tahun 2007 tentang standar proses menyatakan bahwa dalam rangka mengembangkan potensi peserta didik, maka proses pembelajaran harus fleksibel, bervariasi, dan memenuhi standar. Proses pembelajaran pada setiap satuan pendidikan dasar dan menengah harus interaktif, inspiratif, menyenangkan, menantang, dan memotivasi peserta didik untuk berpartisipasi aktif, serta memberikan ruang yang cukup bagi prakarsa, kreativitas, dan kemandirian sesuai dengan bakat, minat, dan perkembangan fisik serta psikologis peserta didik.

Proses pembelajaran yang menekankan pada pemberian pengalaman langsung dapat membuat peserta didik aktif dalam pembelajaran. Salah satu mata pelajaran yang memberikan pengalaman langsung dalam pembelajaran adalah IPA. IPA merupakan pembelajaran yang menarik dan mudah dipahami oleh peserta didik karena berhubungan dengan cara mempelajari diri sendiri dan alam sekitar. Dalam kehidupan sehari-hari, IPA digunakan untuk memenuhi kebutuhan manusia melalui pemecahan masalah - masalah yang dapat diidentifikasikan.

Proses pembelajaran IPA akan menjadikan siswa aktif jika dalam pembelajaran, guru mengaitkan dengan pengalaman yang ada di lingkungan sekitar peserta didik dan menggunakan media pembelajaran yang sesuai dengan materi yang diajarkan. Sumber belajar yang digunakan dalam pembelajaran dapat diperoleh dari alat dan bahan yang ada di lingkungan sekitar. Dalam pembelajaran IPA, model problem based learning dirasa sangat tepat digunakan karena model pembelajaran ini menekankan pada masalah kehidupan nyata yang bermakna bagi siswa dan siswa dapat menyelesaikan masalah tersebut dengan bukti-bukti nyata yang terdapat dalam lingkungan sekitar siswa.

Berdasarkan observasi dalam pembelajaran IPA kelas 5 di SDN 1 Gadu dan SDN 2 Gagakan, guru menerapkan model pembelajaran TPS (Think Pair Share) yang selanjutnya akan disebut dengan think pair share. Dalam pembelajaran IPA menggunakan model pembelajaran think pair share berbantu media visual, guru memberikan permasalahan kepada siswa terkait dengan materi pelajaran yang diajarkan serta menuntut siswa berpasangan untuk memecahkan masalah yang diberikan guru. Dalam kegiatan pembelajaran, masih terdapat siswa yang pasif dan menggantungkan jawaban pada pasangannya serta jumlah pasangan yang terlalu banyak menyebabkan banyak kelompok yang melapor dan perlu dibimbing oleh guru. Jika terdapat perbedaan pendapat antar pasangan tidak ada penengah, dan membutuhkan perhatian khusus dalam penggunaan ruangan kelas serta ketidaksesuaian waktu antara perencanaan dengan pelaksanaannya. Terlihat dalam kegiatan pembelajaran tersebut bahwa pembelajaran kurang efektif dikarenakan terlalu banyak pasangan kelompok yang akan membahas permasalahan yang 
diberikan guru terkait materi pelajaran sehingga terdapat banyak siswa yang kurang fokus dalam pembelajaran. Dalam pembelajaran IPA, siswa akan lebih aktif mengikuti pembelajaran jika difasilitasi oleh media yang menarik. Media yang sesuai dengan model problem based learning adalah media audio visual. Kemampuan media ini dianggap lebih baik dan lebih menarik, karena mengandung kedua unsur jenis media yang pertama dan kedua.

Alasan penggunaan model problem based learning pada mata pelajaran IPA kelas 5 SDN 1 Gadu adalah memberikan pengalaman belajar langsung bagi siswa dengan masalah-masalah yang terkait kehidupan nyata, siswa lebih memahami konsep yang diajarkan karena siswa sendiri yang menemukan konsep tersebut, menumbuhkan rasa sosial, kreativitas, kerja sama, tanggung jawab, keaktifan siswa dalam pembelajaran, serta menjadikan guru lebih variatif sehingga tidak terpaku dengan pembelajaran yang menggunakan model pembelajaran yang digunakan sebelumnya.

Berdasarkan latar belakang yang telah dijabarkan, maka rumusan masalah dalam penelitian ini adalah "apakah terdapat perbedaan tingkat efektivitas antara model problem based learning berbantu media audio visual dengan model pembelajaran think pair share berbantuan media visual terhadap hasil belajar IPA siswa kelas 5 SDN 1 Gadu Sambong Kabupaten Blora semester 2 tahun pelajaran 2014/2015".

\section{KAJIAN TEORI}

\section{Pembelajaran IPA di SD}

Pembelajaran Ilmu Pengetahuan Alam (IPA) di SD pada kurikulum tingkat satuan pendidikan (KTSP), menurut Permendiknas RI No. 22 Tahun 2006 tentang standar isi, dilaksanakan secara inkuiri ilmiah (scientific inquiry) untuk menumbuhkan kemampuan berpikir, bekerja dan bersikap ilmiah serta mengkomunikasikannya sebagai aspek penting kecakapan hidup. Oleh karena itu pembelajaran IPA di SD/MI menekankan pada pemberian pengalaman belajar secara langsung melalui penggunaan dan pengembangan keterampilan proses dan sikap ilmiah. Hal ini didasarkan pada hubungan IPA dengan cara mencari tahu tentang alam secara sistematis, sehingga IPA bukan hanya penguasaan kumpulan pengetahuan yang berupa fakta-fakta, konsep-konsep, atau prinsip-prinsip saja, tetapi juga merupakan suatu proses penemuan.

Pembelajaran IPA diharapkan dapat menjadi wahana bagi peserta didik untuk mempelajari diri sendiri dan alam sekitar, serta prospek pengembangan lebih lanjut dalam menerapkannya di dalam kehidupan sehari-hari. IPA diperlukan dalam kehidupan sehari-hari untuk memenuhi kebutuhan manusia melalui pemecahan 
Efektivitas Model Problem Based Learning Berbantuan Media Audio Visual ditinjau dari Hasil Belajar IPA Siswa Kelas 5 SDN 1 Gadu Sambong - Blora (Adhini Virgiana Dan Wasitohadi)

masalah-masalah yang dapat diidentifikasikan. Penerapan IPA perlu dilakukan secara bijaksana agar tidak berdampak buruk terhadap lingkungan. Di tingkat SD/MI diharapkan ada penekanan pembelajaran Salingtemas (Sains, lingkungan, teknologi, dan masyarakat) yang diarahkan pada pengalaman belajar untuk merancang dan membuat suatu karya melalui penerapan konsep IPA dan kompetensi bekerja ilmiah secara bijaksana.

\section{Model Problem Based Learning}

Menurut Dutch dalam Amir (2009:21), "problem based learning (PBL) merupakan model instruksional yang menantang siswa untuk belajar, bekerja sama dengan kelompok untuk mencari solusi suatu masalah dalam dunia nyata".

Menurut Agus N. Cahyo (2013:283), "pembelajaran berdasarkan masalah atau problem based learning adalah suatu model pembelajaran yang didasarkan pada prinsip menggunakan masalah sebagai titik awal akuisisi dan integrasi pengetahuan baru".

Menurut Ngalimun (2014:89), "pembelajaran berdasarkan masalah (problem based learning) merupakan salah satu model pembelajaran inovatif yang dapat memberikan kondisi belajar aktif kepada siswa".

Berdasarkan pendapat para ahli di atas, maka dapat disimpulkan bahwa model problem based learning adalah model pembelajaran inovatif yang diawali dengan pemberian masalah atau topik masalah kepada siswa di mana masalah tersebut dialami dalam kehidupan sehari-hari siswa dan siswa bekerja sama dengan kelompok untuk menyelesaikan masalah tersebut dan menemukan pengetahuan baru.

Menurut Ibrahim dan Nur (2000) dalam Agus N. Cahyo (2013:285), pembelajaran berbasis masalah (problem based learning) memiliki beberapa kelebihan, diantaranya: (1) Siswa lebih memahami konsep yang diajarkan sebab mereka sendiri yang menemukan konsep tersebut, (2) Melibatkan secara aktif memecahkan masalah dan menuntut keterampilan berpikir siswa yang lebih tinggi, (3) Pengetahuan tertanam berdasarkan skemata yang dimiliki siswa sehingga pembelajaran lebih bermakna, (4) Siswa dapat merasakan manfaat pembelajaran, sebab masalah-masalah yang diselesaikan langsung dikaitkan dengan kehidupan nyata, hal ini dapat meningkatkan motivasi dan ketertarikan siswa terhadap bahan yang dipelajari, (5) Menjadikan siswa lebih mandiri dan dewasa, mampu memberi aspirasi dan menerima pendapat orang lain, menanamkan sikap sosial yang positif di antara siswa, (6) Pengondisian siswa dalam belajar kelompok yang saling 
berinteraksi terhadap pembelajar dan temannya, sehingga pencapaian ketuntasan belajar siswa dapat diharapkan.

Menurut Arends (2008:57), terdapat lima tahapan dalam model problem based learning diantaranya: (1) Memberikan orientasi tentang permasalahannya kepada siswa, (2) Mengorganisasikan siswa untuk meneliti, (3) Membantu menyelidiki secara mandiri atau kelompok, (4) Mengembangkan dan mempresentasikan hasil kerja, (5) Menganalisis dan mengevaluasi proses mengatasi masalah.

\section{Model Pembelajaran Think Pair Share}

Menurut Trianto (2010:81), "model pembelajaran think pair share atau berpikir berpasangan berbagi adalah jenis pembelajaran kooperatif yang dirancang untuk mempengaruhi pola interaksi siswa".

Suyatno (2009:54), "think pair share adalah model pembelajaran kooperatif yang memiliki prosedur ditetapkan secara eksplisit memberikan waktu lebih banyak kepada sisswa untuk memikirkan secara mendalam tentang apa yang dijelaskan atau dialami (berpikir, menjawab, dan saling membantu satu sama lain.

Menurut Anita Lie (2005:57), "model pembelajaran think pair share adalah pembelajaran yang memberi siswa kesempatan untuk bekerja sendiri dan bekerja sama dengan orang lain.”

Berdasarkan pendapat ahli di atas, dapat disimpulkan bahwa model pembelajaran think pair share adalah model pembelajaran yang memungkinkan siswa untuk bekerja sama dalam kelompok-kelompok kecil dengan tahap berpikir, berpasangan, dan berbagi.

Menurut Anita Lie (2002:45), kelebihan model pembelajaran think pair share antara lain: (1) Meningkatkan partisipasi siswa, siswa saling bekerja sama antara satu dengan yang lainnya dalam pasangan, (2) Cocok untuk tugas sederhana, (3) Lebih banyak kesempatan untuk kontribusi masing-masing anggota kelompok, (4) Interaksi lebih mudah , (5) Membentuk kelompoknya lebih mudah dan lebih cepat karena siswa dapat berpasangan dengan teman sebangku.

Menurut Agus Suprijono (2009:91) mengemukakan langkah-langkah model pembelajaran think pair share sebagai berikut: (1) Thinking (berpikir), guru mengajukan pertanyaan atau isu yang terkait dengan pelajaran untuk dipikirkan oleh peserta didik dan guru memberikan kesempatan untuk memikirkan jawabannya, (2) Pairing (berpasangan), guru meminta peserta didik berpasang-pasang, memberi kesempatan pasangan-pasangan untuk berdiskusi serta diharapkan diskusi dapat memperdalam makna dari jawaban yang telah dipikirkannya melalui intersubjektif dengan pasangannya, (3) Sharing (berbagi), pada tahap ini, hasil diskusi inter 
Efektivitas Model Problem Based Learning Berbantuan Media Audio Visual ditinjau dari Hasil Belajar IPA Siswa Kelas 5 SDN 1 Gadu Sambong - Blora (Adhini Virgiana Dan Wasitohadi)

subjektif tiap-tiap pasangan hasilnya dibicarakan dengan pasangan seluruh kelas serta diharapkan terjadi tanya jawab yang mendorong pada pengonstruksian pengetahuan secara integratif.

\section{Media Audio Visual}

Menurut Wina Sanjaya (2010:172), "media audio visual adalah jenis media yang selain mengandung unsur suara juga mengandung unsur gambar yang bisa dilihat, misalnya rekaman video, film, slide suara, dan lain sebagainya". Menurut Sri Anitah (2012:51), "media audio visual adalah media yang menunjukkan unsur auditif (pendengaran) maupun visual (penglihatan), jadi dapat dipandang maupun didengar suaranya." Sedangkan menurut Djamarah (2006:124), "media audio visual adalah media yang mempunyai unsur suara dan unsur gambar". Berdasarkan pendapat ahli tersebut, dapat disimpulkan bahwa media audio visual adalah media yang mempunyai unsur suara dan unsur gambar yang dapat dipandang maupun didengar suaranya.

\section{Media Visual}

Menurut Djamarah (2006: 124), "media visual adalah media yang hanya mengandalkan indera penglihatan". Sedangkan menurut M Sobry Sutikno (2009: 19), "media visual adalah media yang dapat dilihat dengan panca indera". Berdasarkan pendapat ahli tersebut, dapat disimpulkan bahwa media visual merupakan media yang dapat dilihat dengan indera penglihatan.

\section{Hasil Belajar}

Menurut Darmansyah (2006:13), "hasil belajar adalah hasil penelitian terhadap kemampuan siswa yang ditentukan dalam bentuk angka". Ini berarti ada proses belajar yang merupakan kemampuan siswa yang harus diukur melalui angka. Sedangkan menurut Sudjana (2004:22), "hasil belajar adalah kemampuan yang dimiliki peserta didik"

Berdasarkan pendapat dari beberapa tokoh di atas, dapat disimpulakan bahwa hasil belajar adalah besarnya skor yang diperoleh siswa melalui pengukuran proses belajar dan pengukuran hasil belajar sebagai hasil dari proses belajar.

Beberapa penelitian yang relevan dengan model problem based learning yang diterapkan untuk mengetahui perbedaan hasil belajar IPA, diantaranya :

Menurut penelitian Merinda Dian Prametasari pada tahun 2012 dengan judul "Efektivitas penggunaan model pembelajaran berbasis masalah (problem based learning) terhadap hasil belajar IPA siswa kelas V di SD Gugus Hasanudin Salatiga Semester II Tahun Ajaran 2011/2012", menyimpulkan bahwa hasil penelitian 
menunjukkan ada efektifitas penggunaan model pembelajaran berbasis masalah (problem based learning-PBL) terhadap hasil belajar IPA siswa kelas V di SD Gugus Hasanudin Salatiga Semester II Tahun Ajaran 2011/2012. Hal ini ditunjukkan dengan adanya perbedaan rata-rata dari hasil belajar kelas kontrol dan kelas eksperimen dengan perolehan rata-rata nilai tes siswa kelas kontrol lebih rendah dari pada rata-rata nilai tes siswa kelas eksperimen, yaitu 74,53 < 83,38 dengan perbedaan rata-rata (mean difference) sebesar 8,851. Perbedaan tersebut ditinjau dari kesignifikansiannya nampak $t_{\text {hitung }}>\mathrm{t}_{\text {tabel }}(3.201>1.674)$ dengan taraf signifikansi diperoleh angka 0,002 <0,05. Kelebihan dari penelitian ini dapat dilihat dari hasil belajar siswa kelas eksperimen dengan model pembelajaran berbasis masalah (Problem Based Learning-PBL) lebih tinggi dari kelas kontrol yang menggunakan pembelajaran konvensional. Namun di sisi lain dalam penelitian ini terdapat kelemahan yaitu membandingkan dengan model pembelajaran yang tidak seimbang antara model problem based learning dengan metode ceramah serta dalam hasil penelitian tidak menjelaskan hasil observasi untuk aktivitas guru dan siswa. Untuk itu dalam penelitian ini akan dilaksanakan menggunakan model pembelajaran yang seimbang yaitu model problem based learning dengan model pembelajaran think pair share yang sama-sama menekankan permasalahan dan menjelaskan hasil observasi untuk aktivitas guru dan siswa pada hasil penelitian sehingga mudah untuk melakukan refleksi dalam pembelajaran.

Menurut hasil penelitian yang dilakukan oleh Nurkhikmah dalam Journal of Elementary Education Universitas Negeri Semarang pada tahun 2013, dengan judul penelitian "Keefektifan Penerapan Model Problem Based Learning (PBL) Terhadap Peningkatan Kualitas Pembelajaran IPA", menyimpulkan bahwa ada perbedaan hasil belajar yang signifikan antara siswa kelas V SD yang memperoleh pembelajaran materi Daur Air dengan menggunakan model pembelajaran PBL dan yang mendapat pembelajaran dengan metode ceramah. Dilihat dari levene's test for equality of variances nilai yaitu 0,314 dengan nilai signifikansi 0,577 . Karena nilai signifikan lebih besar dari $(0,577>0,05)$, maka varians berasal dari populasi yang sama atau homogen (Triton 2006:175). Berdasarkan output hasil uji t, nilai t pada equal variances assummed 2,058 dan nilai signifikansi dua sisi (sig.2-tailed) sebesar 0,44. Dari hasil output independent t-test, diperoleh signifikansi dua sisi (sig.2-tailed) sebesar 0,44. Karena signifikansi dua sisi sebesar 0,44 kurang dari $0,05(0,44<0,05)$, maka $\mathrm{H}_{0}$ ditolak dan $\mathrm{H}_{\mathrm{a}}$ diterima (Triton 2006: 176). Kelebihan dari penelitian ini adalah hasil belajar siswa kelas eksperimen dengan model pembelajaran berbasis masalah (Problem Based Learning-PBL) lebih tinggi dari kelas kontrol yang menggunakan metode ceramah. Namun di sisi lain dalam penelitian ini terdapat kelemahan yaitu membandingkan dengan model 
pembelajaran yang tidak seimbang antara model problem based learning dengan metode ceramah dan dalam penelitian juga tidak menjelaskan pelaksanaan treatment sehingga sulit untuk melakukan refleksi terhadap pembelajaran.. Untuk itu dalam penelitian ini akan dilaksanakan menggunakan model pembelajaran yang seimbang yaitu model problem based learning dengan model pembelajaran think pair share yang sama-sama menekankan permasalahan dan menjelaskan pelaksanaan treatment dalam pembelajaran.

\section{Hipotesis Penelitian}

Berdasarkan uraian di atas yang dikemukakan, maka diajukan hipotesis yang hendak diuji dalam penelitian, yaitu :

1. $\mathrm{H}_{0}=$ tidak terdapat perbedaan tingkat efektivitas antara model problem based learning berbantu media audio visual dengan model pembelajaran think pair share berbantu media visual terhadap hasil belajar IPA siswa kelas 5 SDN 1 Gadu Sambong Kabupaten Blora semester 2 tahun pelajaran 2014/2015.

2. $\mathrm{H}_{\mathrm{a}}=$ terdapat perbedaan tingkat efektivitas antara model problem based learning berbantu media audio visual dengan model pembelajaran think pair share berbantu media visual terhadap hasil belajar IPA siswa kelas 5 SDN 1 Gadu Sambong Kabupaten Blora semester 2 tahun pelajaran 2014/2015.

\section{METODE PENELITIAN}

\section{Jenis Penelitian}

Penelitian ini menggunakan jenis penelitian eksperimen. Menurut Sugiyono (2011:72), "penelitian eksperimen dapat diartikan sebagai penelitian yang digunakan untuk mencari pengaruh perlakuan terhadap yang lain dalam kondisi yang terkendalikan".

\section{Desain Penelitian}

Penelitian ini, menggunakan quasi experimental design atau penelitian eksperimen semu. Pada penelitian eksperimen semu terbagi dua bentuk desain yaitu time-series design dan nonequivalent control group design. Bentuk desain yang digunakan dalam penelitian ini adalah nonequivalent control group design. Sugiyono (2011:79) menyatakan bahwa: "desain ini hampir sama dengan pretest posttest control group design, hanya pada desain ini kelompok eksperimen maupun kelompok kontrol tidak dipilih secara random".

Desain penelitian nonequivalent control group design dapat digambarkan sebagai berikut: 


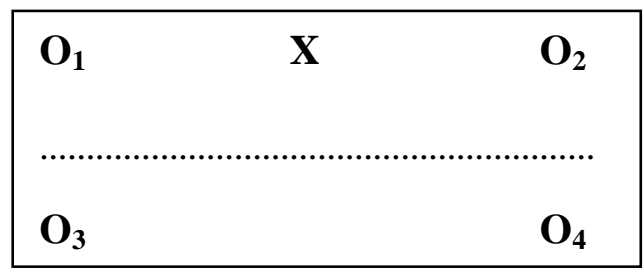

Gambar 1

Desain nonequivalent control group design

Keterangan :

$\mathrm{X} \quad$ : Perlakuan model problem based learning berbantu media audio visual

$\mathrm{O}_{1} \quad$ : Pengukuran awal hasil belajar (pretest) pada kelas eksperimen

$\mathrm{O}_{2} \quad$ : Pengukuran akhir hasil belajar (posttest) pada kelas eksperimen

$\mathrm{O}_{3} \quad$ : Pengukuran awal hasil belajar (pretest) pada kelas kontrol

$\mathrm{O}_{4} \quad$ : Pengukuran akhir hasil belajar (posttest) pada kelas kontrol

\section{Subjek Penelitian}

Subjek penelitian yang digunakan dalam penelitian eksperimen ini adalah siswa kelas 5 di SDN 1 Gadu sebagai kelas eksperimen berjumlah 34 siswa terdiri dari 17 siswa laki-laki dan 17 siswa perempuan serta siswa kelas 5 di SDN 2 Gagakan sebagai kelas kontrol yang berjumlah 30 siswa terdiri dari 14 siswa lakilaki dan 16 siswa perempuan.

\section{Variabel Penelitian}

Dalam penelitian ini terdapat dua macam variabel, yaitu variabel bebas dan variabel terikat.

1. Variabel bebas (independent variable), variabel yang sering disebut sebagai variabel stimulus, predictor, antecedent. Variabel bebas adalah variabel yang mempengaruhi atau yang menjadi sebab perubahannya atau timbulnya variabel terikat (Sugiyono, 2011:39). Variabel bebas dalam penelitian ini adalah model problem based learning berbantu media audio visual.

$\mathrm{X}$ : Model problem based learning berbantu media audio visual

2. Variabel terikat (dependent variable), variabel ini sering disebut sebagai variabel output, kriteria, konsekuen. Variabel terikat merupakan variabel yang dipengaruhi atau yang menjadi akibat, karena adanya variabel bebas (Sugiyono, 2011:39). Variabel terikat dalam penelitian ini adalah hasil belajar IPA.

$\mathrm{Y}$ : Hasil belajar IPA

\section{Definisi Operasional}


Efektivitas Model Problem Based Learning Berbantuan Media Audio Visual ditinjau dari Hasil Belajar IPA Siswa Kelas 5 SDN 1 Gadu Sambong - Blora (Adhini Virgiana Dan Wasitohadi)

Menurut Sugiyono (2012:31), "definisi operasional adalah penentuan konstrak atau sifat yang akan dipelajari sehingga menjadi variabel yang dapat diukur". Dalam penelitian ini, definisi operasional mengenai model problem based learning, media audio visual, dan hasil belajar IPA.

Model pembelajaran problem based learning adalah model pembelajaran inovatif yang diawali dengan pemberian masalah atau topik masalah kepada siswa di mana masalah tersebut dialami dalam kehidupan sehari-hari siswa dan siswa bekerja sama dengan kelompok untuk menyelesaikan masalah tersebut untuk menemukan pengetahuan baru. Dalam penelitian ini model problem based learning merupakan perlakuan atau treatment yang diterapkan dalam pembelajaran IPA KD 7.6 Mengidentifikasi peristiwa alam yang terjadi di Indonesia dan dampaknya bagi makhluk hidup dan lingkungan, yang langkah-langkahnya adalah orientasi permasalahan, mengorganisasikan siswa untuk meneliti, investigasi mandiri dan investigasi kelompok, mengembangkan dan mempresentasikan hasil laporan diskusi, serta menganalisis dan mengevaluasi permasalahan.

Media audio visual adalah media yang mempunyai unsur suara dan unsur gambar yang dapat dipandang maupun di dengar suaranya.

Hasil belajar IPA adalah besarnya skor yang diperoleh siswa melalui pengukuran proses belajar dan pengukuran hasil belajar kognitif siswa pada mata pelajaran IPA dengan materi Peristiwa Alam.

\section{Teknik dan Instrumen Pengumpulan Data}

Teknik yang digunakan dalam pengumpulan data ini yaitu tes dan observasi. Tes yang digunakan dalam penelitian ini adalah tes formatif. Bentuk soal dari tes tersebut adalah pilihan ganda. Tes digunakan untuk mengetahui hasil belajar IPA siswa kelas 5 dengan materi "Peristiwa Alam". Teknik observasi ini digunakan untuk mengamati proses pembelajaran di kelas. Proses pembelajaran yang diamati adalah kegiatan guru dalam mengajar di dalam kelas serta aktivitas siswa dalam pembelajaran, baik di kelas eksperimen maupun di kelas kontrol.

Instrumen yang digunakan dalam penelitian ini adalah butir soal tes dan lembar observasi. Sebelum dibuat butir soal maka disusun kisi-kisi soal terlebih dahulu. Dalam lembar observasi proses pembelajaran yang diamati adalah kegiatan guru dalam mengajar di dalam kelas serta aktivitas siswa dalam pembelajaran, baik di kelas eksperimen maupun di kelas kontrol.

\section{Uji Instrumen}


Uji instrumen yang dilakukan dalam penelitiasn ini adalah uji validitas dan reliabilitas. Uji validitas berarti instrumen tersebut dapat digunakan untuk mengukur apa yang seharusnya diukur (Sugiyono, 2011:172). Kriteria kevalidan soal adalah jika $r_{\text {hitung }}>r_{\text {tabel }}$ maka koefisien item soal tersebut valid dan jika $r_{\text {hitung }}$ negatif dan $r_{\text {hitung }} \leq r_{\text {tabel }}$ maka koefisien item soal tidak valid, $r_{\text {tabel }}$ diperoleh pada taraf kepercayaan 95\% $(\alpha=0,05)$ dengan derajat kebebasan $(\mathrm{dk})=\mathrm{n}-2$. Instrumen soal tes yang akan diberikan pada kelas eksperimen dan kelas kontrol dilakukan uji coba terlebih dahulu. Instrumen diujikan di kelas 6 SDN 2 Gagakan pada tanggal 02 Maret 2015. Dalam uji coba soal tes ini , jumlah data siswa kelas 6 sebanyak 23 siswa sehingga dapat diperoleh $(\mathrm{N}=23)$. Untuk $\mathrm{N}=23$ dan taraf signifikan 5\%, nilai $\mathrm{r}$ adalah 0,413 . Sehingga butir soal dapat dikatakan valid jika $r$ hasil perhitungan $\geq$ 0,413. Perhitungan dilakukan dengan bantuan SPSS versi 22,0. Setelah dilakukan perhitungan uji validitas dengan bantuan SPSS 22,0, dari 40 butir soal diperoleh hasil butir soal yang tidak valid sebanyak 13 soal karena koefissien corrected item to total correlation pada nomor-nomor tersebut $\leq 0,413$. Butir soal yang tidak valid ini tidak digunakan dalam penelitian.

Uji reliabilitas instrumen adalah uji ketetapan atau keajegan instrumen tersebut dalam menilai apa yang dinilainya. Artinya, kapan pun alat penilaian tersebut digunakan akan memberikan hasil yang sama. Hasil penelitian yang reliabel, bila terdapat kesamaan data dalam waktu yang berbeda (Sugiyono, 2011:172). Uji reliabilitas tes dalam penelitian ini dilakukan dengan bantuan SPSS 22,0 dan intrepetasi terhadap koefisien reliabilitas yang dinyatakan dalam Cronbach's Alpha. Besarnya Cronbach's Alpha yang diperoleh dari hasil uji reliabilitas 40 butir soal adalah 0,950. Nilai Cronbach's Alpha 0,950 berada diantara koefisien korelasi 0,800 - 1,00, maka butir soal yang di uji cobakan termasuk kriteria reliabilitas sangat tinggi.

\section{Uji Prasyarat}

Uji prasyarat yang dilakukan dalam penelitian ini mencakup uji normalitas dan homogenitas data. Uji normalitas dilakukan untuk mengetahui normal atau tidaknya distribusi data yang akan dianalisis. Uji normalitas data menggunakan uji Kolmogorov-Smirnov. Menurut Duwi Priyatno (2010:71), "data dinyatakan berdistribusi normal jika signifikansi lebih dari 0,05". Hal ini berarti data dinyatakan berdistribusi normal jika nilai signifikansinya $>0,05$, sebaliknya jika nilai signifikansi $<0,05$ berarti dinyatakan data berdistribusi tidak normal.

Uji homogenitas bertujuan untuk mengetahui apakah kelas eksperimen dan kelas kontrol mempunyai varian yang sama atau tidak. Dalam uji homogenitas ini jika nilai signifikansinya > 0,05 maka data kedua kelas berasal dari kelas yang 
Efektivitas Model Problem Based Learning Berbantuan Media Audio Visual ditinjau dari Hasil Belajar IPA Siswa Kelas 5 SDN 1 Gadu Sambong - Blora (Adhini Virgiana Dan Wasitohadi)

homogen sebaliknya jika signifikansi hasil perhitungan $<0,05$ maka data kedua kelas berasal dari kelas yang tidak homogen.

\section{Teknik Analisis Data}

Pada tahap pengujian hipotesis, teknik analisis data yang digunakan dalam penelitian ini adalah menggunakan uji t-test (Independent Samples T-Test) dengan bantuan SPSS for windows versi 22.0. Uji ini digunakan untuk mengetahui ada atau tidaknya perbedaan rata-rata antara kedua kelas. Jika ada perbedaan, rata-rata manakah yang lebih tinggi.

Cara menganalisis data dengan menggunakan uji $t$-test yaitu jika $t_{\text {hitung }}<\mathrm{t}_{\text {tabel }}$ $\left\{\right.$ nilai $t_{\text {tabel }}$ dicari menggunakan rumus pada Microsoft Excel $\left.=\operatorname{tinv}(0,05 ; \mathrm{df})\right\}$ dan diperoleh signifikansi $>0,05$ maka $\mathrm{H}_{0}$ diterima dan $\mathrm{H}_{\mathrm{a}}$ ditolak, tetapi jika $\mathrm{t}_{\text {hitung }}>$ $\mathrm{t}_{\text {tabel }}$ dan diperoleh signifikansi $<0,05$ maka $\mathrm{H}_{0}$ ditolak dan $\mathrm{H}_{\mathrm{a}}$ diterima (Duwi Priyatno 2010: 20).

\section{HASIL PENELITIAN DAN PEMBAHASAN}

\section{Pelaksanaan Penelitian}

Pelaksanaan penelitian pada kelas eksperimen dimulai dari mengidentifikasi masalah di lapangan dengan melakukan observasi kepada siswa dan guru kelas 5 SDN 1 Gadu. Tahap selanjutnya yang dilakukan adalah melakukan pengambilan data awal yaitu dengan memberikan pretest tentang materi "Daur Air" untuk mengetahui apakah hasil belajar antara kelas eksperimen dan kelas kontrol dalam keadaan setara (homogen). Pemberian perlakuan (treatmen)t di SDN 1 Gadu sebagai kelas eksperimen dilakukan tiga kali pertemuan. Setelah diberikan pembelajaran kemudian siswa diberikan posttest untuk menguji pemahaman siswa terkait materi Peristiwa Alam.

Hasil observasi respon siswa terlihat dari 10 aspek yang diamati telah dilaksanakan semua oleh siswa dengan persentase $100 \%$. Hal ini menunjukkan bahwa respon siswa dalam pembelajaran IPA menggunakan model problem based learning berbantu media audio visual sangat baik.

Pelaksanaan penelitian pada kelas kontrol dimulai dari mengidentifikasi masalah di lapangan dengan melakukan observasi kepada siswa dan guru kelas 5 SDN 2 Gagakan. Tahap selanjutnya yang dilakukan adalah melakukan pengambilan data awal yaitu dengan memberikan pretest tentang materi "Daur Air" untuk mengetahui apakah hasil belajar antara kelas eksperimen dan kelas kontrol dalam keadaan setara (homogen). Pembelajaran di SDN 2 Gagakan sebagai kelas kontrol 
dilakukan tiga kali pertemuan. Setelah diberikan pembelajaran kemudian siswa diberikan posttest untuk menguji pemahaman siswa terkait materi Peristiwa Alam.

Hasil observasi respon siswa terlihat dari 10 aspek yang diamati telah dilaksanakan siswa sebanyak 7 aspek dengan persentase $70 \%$. Hal ini menunjukkan bahwa respon siswa dalam pembelajaran IPA menggunakan model pembelajaran think pair share berbantu media visual cukup baik.

\section{Hasil Penelitian}

Data skor hasil belajar IPA yang diperoleh dari kelas eksperimen yaitu kelas 5 SDN 1 Gadu dan kelas kontrol yaitu kelas 5 SDN 2 Gagakan disajikan dan dianalisis secara deskriptif. Data hasil belajar kelas eksperimen. Untuk memperjelas gambaran data hasil belajar IPA kelas eksperimen, akan disajikan grafik garis distribusi skor hasil belajar IPA dari hasil posttest kelas eksperimen berikut ini:

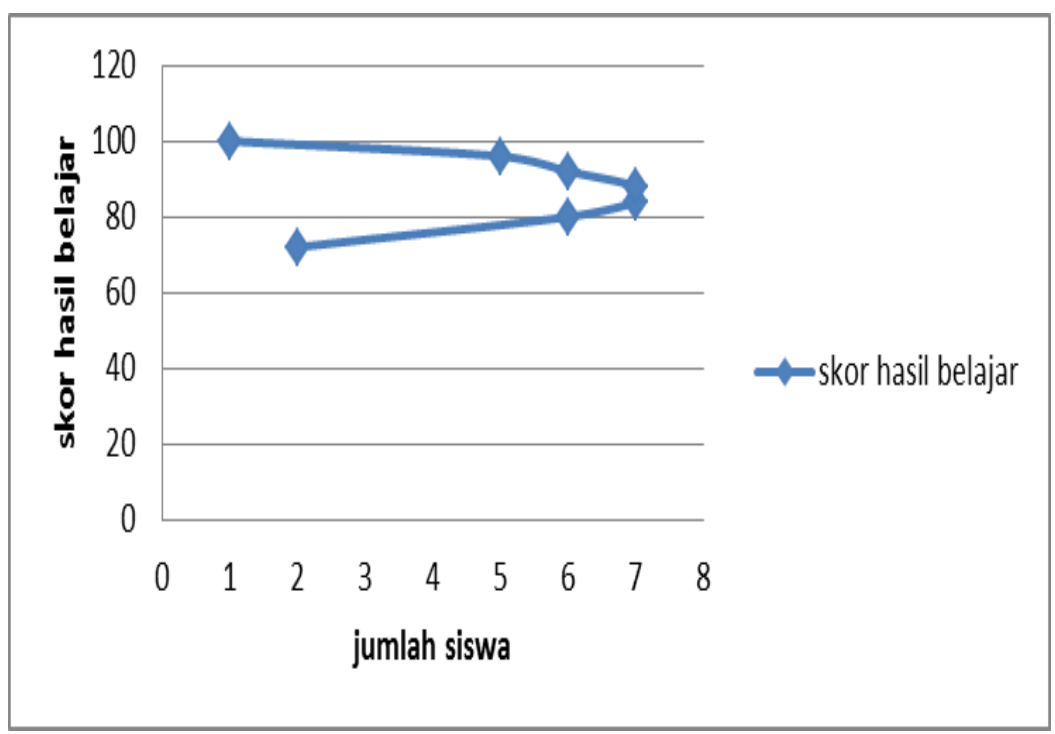

Gambar 2

Grafik Distribusi Skor Hasil Belajar Kelas Eksperimen

Berdasarkan grafik garis distribusi skor hasil belajar IPA, dapat terlihat bahwa siswa yang mendapatkan skor 72 sebanyak 2 siswa, siswa yang mendapatkan skor 80 sebanyak 6 siswa, siswa yang mendapatkan skor 84 sebanyak 7 orang, siswa yang mendapatkan skor 88 sebanyak 7 orang, siswa yang mendapatkan skor 92 sebanyak 6 siswa, siswa yang mendapatkan skor 96 sebanyak 5 orang dan siswa yang mendapatkan skor 100 sebanyak 1 orang. 
Efektivitas Model Problem Based Learning Berbantuan Media Audio Visual ditinjau dari Hasil Belajar IPA Siswa Kelas 5 SDN 1 Gadu Sambong - Blora (Adhini Virgiana Dan Wasitohadi)

Untuk memperjelas gambaran data hasil belajar IPA kelas kontrol, akan disajikan grafik garis distribusi skor hasil belajar IPA dari hasil posttest kelas kontrol berikut ini:

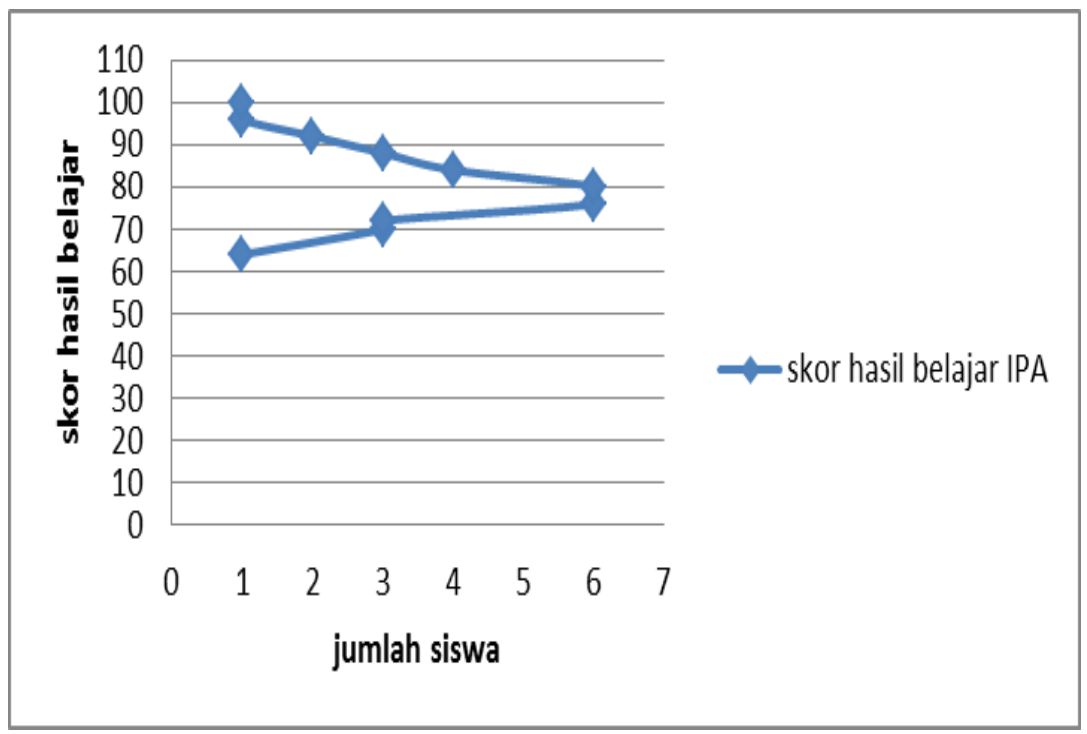

Gambar 3

Grafik Distribusi Skor Hasil Belajar Kelas Kontrol

Berdasarkan grafik garis distribusi skor hasil belajar IPA, dapat terlihat bahwa siswa yang mendapatkan skor 64 sebanyak 1 siswa, siswa yang mendapatkan skor 70 sebanyak 3 siswa, siswa yang mendapatkan skor 72 sebanyak 3 siswa, siswa yang mendapatkan skor 76 sebanyak 6 siswa, siswa yang mendapatkan skor 80 sebanyak 6 siswa, siswa yang mendapatkan skor 84 sebanyak 4 siswa, siswa yang mendapatkan skor 88 sebanyak 3 siswa, siswa yang mendapatkan skor 92 sebanyak 2 siswa, siswa yang mendapatkan skor 96 sebanyak 1 siswa dan siswa yang mendapatkan skor 100 sebanyak 1 siswa.

\section{Uji prasyarat}

\section{Uji normalitas}

Berikut ini disajikan tabel hasil uji normalitas hasil belajar IPA pada kelas eksperimen dan kelas kontrol: 
Tabel 2

Hasil Uji Normalitas Skor Hasil Belajar IPA

One-Sample Kolmogorov-Smirnov Test

\begin{tabular}{|ll|r|r|}
\hline & & \multicolumn{1}{|c|}{$\begin{array}{c}\text { Kelas } \\
\text { Eksperimen }\end{array}$} & Kelas Kontrol \\
\hline $\mathrm{N}$ & & 34 & 30 \\
Normal Parameters $^{\mathrm{a}, \mathrm{b}}$ & Mean & 87,0588 & 80,2000 \\
& Std. & 6,82660 & 8,39294 \\
& Deviation &, 118 &, 143 \\
Most Extreme & Absolute &, 114 &, 143 \\
Differences & Positive &,- 118 &,- 079 \\
& Negative &, 118 &, 143 \\
Test Statistic & &, $200^{\mathrm{c}, \mathrm{d}}$ &, $121^{\mathrm{c}}$ \\
Asymp. Sig. (2-tailed) & &
\end{tabular}

a. Test distribution is Normal.

b. Calculated from data.

c. Lilliefors Significance Correction.

Berdasarkan tabel one sample Kolmogorov smirnov test diperoleh hasil bahwa data uji normalitas kelas kelas eksperimen dan kelas kontrol yang didapat berdistribusi normal. Hal ini dibuktikan dengan hasil signifikansi > 0,05 yaitu kelas eksperimen sebesar 0,200 dan kelas kontrol sebesar 0,121.

\section{Uji homogenitas}

Hasil dari uji homogenitas data hasil belajar IPA siswa kelas 5 SDN 1 Gadu sebagai kelas eksperimen dan siswa kelas 5 SDN 2 Gagakan sebagai kelas kontrol terlihat pada tabel berikut ini:

Tabel 3

Hasil Uji Homogenitas Skor Hasil Belajar IPA

Test of Homogeneity of Variances

Posttest

\begin{tabular}{|c|c|c|c|}
\hline $\begin{array}{l}\text { Levene } \\
\text { Statistic }\end{array}$ & df1 & df2 & Sig. \\
\hline, 775 & 1 & 62 &, 382 \\
\hline
\end{tabular}


Efektivitas Model Problem Based Learning Berbantuan Media Audio Visual ditinjau dari Hasil Belajar IPA Siswa Kelas 5 SDN 1 Gadu Sambong - Blora (Adhini Virgiana Dan Wasitohadi)

Dari hasil uji homogenitas dapat diketahui signifikansi sebesar 0,382 $(0,382<$ 0,05), maka dapat disimpulkan bahwa kedua variansi adalah sama (varian kelas eksperimen dan kelas kontrol).

\section{Uji T-Test}

Teknik analisis data yang dilakukan dalam penelitian ini menggunakan uji $t$ test (Independent Samples T-Test) dengan menggunakan bantuan SPSS for windows versi 22.0. Uji ini digunakan untuk mengetahui ada atau tidaknya perbedaan ratarata skor posttest hasil belajar IPA antara kedua kelas. Hasil uji t-test dari skor posttest hasil belajar IPA kelas kontrol dan kelas eksperimen disajikan pada tabel berikut ini:

Tabel 4

Hasil Uji T-Test Skor Hasil Belajar IPA

\begin{tabular}{|c|c|c|c|c|c|c|c|c|c|c|}
\hline & \multicolumn{2}{|c|}{$\begin{array}{c}\text { Levene's } \\
\text { Test }\end{array}$} & \multicolumn{7}{|c|}{ t-test for Equality of Means } \\
\hline & & \multirow[b]{2}{*}{$\mathrm{F}$} & \multirow[b]{2}{*}{ Sig. } & \multirow[b]{2}{*}{$\mathrm{T}$} & \multirow[b]{2}{*}{ Df } & \multirow{2}{*}{$\begin{array}{c}\text { Sig. } \\
(2- \\
\text { tailed })\end{array}$} & \multirow{2}{*}{$\begin{array}{l}\text { Mean } \\
\text { Diff. }\end{array}$} & \multirow{2}{*}{$\begin{array}{l}\text { Std. } \\
\text { Error } \\
\text { Diff. }\end{array}$} & \multicolumn{2}{|c|}{ 95\% Confidence } \\
\hline & & & & & & & & & Lower & Upper \\
\hline $\begin{array}{l}\text { Post } \\
\text { test }\end{array}$ & $\begin{array}{c}\text { Equal } \\
\text { variances } \\
\text { assumed }\end{array}$ & ,775 & ,382 & 3,603 & 62 & ,001 & 6,8588 & 1,90361 & 3,05357 & 10,66408 \\
\hline & $\begin{array}{l}\text { Equal } \\
\text { variances } \\
\text { not } \\
\text { assumed }\end{array}$ & & & 3,557 & 55,977 &, 001 & 6,8588 & 1,92840 & 2,99575 & 10,72190 \\
\hline
\end{tabular}

Berdasarkan tabel di atas dapat diketahui nilai $t_{\text {hitung }}$ sebesar 3,603 pada derajat kebebasan (df) sebesar 62 dan hasil signifikansi sebesar 0,001. Perbedaan rata-rata (mean difference) sebesar 6,8588 (87,0588-80,2000) dan perbedaan berkisar antara 3,05357 sampai 10,66408 terlihat pada lower dan upper, sedangkan nilai $\mathrm{t}_{\text {tabel }}$ adalah 1,999 .

\section{Pembahasan}

Berdasarkan analisis data yang sudah dilakukan terlihat perbedaan rata-rata dari kelas eksperimen dan kelas kontrol. Hasil belajar IPA kelas eksperimen dengan jumlah siswa 34 mempunyai nilai terendah 72 dan nilai tertinggi 100. Sedangkan 
hasil belajar IPA kelas kontrol dengan jumlah siswa 30 mempunyai nilai terendah 64,00 dan nilai tertinggi 100 .

Berdasarkan hasil uji t-test, $\mathrm{t}_{\text {hitung }}$ sebesar 3,603 dan signifikansi sebesar 0,001, hal ini menunjukkan $t_{\text {hitung }}>\mathrm{t}_{\text {tabel }}$ yaitu 3,603 >1,999 dan hasil signifikansi lebih kecil dari $0,05(0,001<0,05)$ maka $\mathrm{H}_{0}$ ditolak dan $\mathrm{H}_{\mathrm{a}}$ diterima. Hal ini berarti bahwa terdapat perbedaan tingkat efektivitas antara model problem based learning berbantu media audio visual dengan model pembelajaran think pair share berbantu media visual terhadap hasil belajar IPA siswa kelas 5 SDN 1 Gadu Sambong Kabupaten Blora Semester 2 tahun pelajaran 2014/2015. Perbedaan tingkat efektivitas ini dilihat dari uji t-test dan perbedaan rata-rata kedua kelas. Hal ini berarti model pembelajaran problem based learning berbantuan media audio visual lebih efektif daripada model pembelajaran think pair share berbantu media visual.

\section{SIMPULAN DAN SARAN}

\section{Simpulan}

Berdasarkan hasil penelitian dan pembahasan, maka dapat disimpulkan bahwa terdapat perbedaan tingkat efektivitas antara model problem based learning berbantu media audio visual dengan model pembelajaran think pair share berbantu media visual terhadap hasil belajar IPA siswa kelas 5 SDN 1 Gadu Kecamatan Sambong Kabupaten Blora semester 2 tahun 2014/2015. Terbukti hal ini ditunjukkan oleh hasil uji t-test sebesar 3,603 > 1,999 dan signifikansi sebesar 0,001 $<0,05$. Perbedaan rata-rata kelas eksperimen > rata-rata kelas kontrol yaitu 87,0588 $>80,2000$.

\section{Saran}

Berdasarkan kesimpulan di atas dapat diberikan beberapa saran sebagai berikut:

Bagi siswa, siswa hendaknya meningkatkan keaktifan belajar dalam penggunaan model problem based learning berbantu media audio visual sehingga pemahaman konsep siswa akan lebih baik dan dapat memecahkan masalah-masalah yang terkait dengan materi pelajaran serta menumbuhkan rasa sosial, kreativitas, kerja sama, dan tanggung jawab dalam pembelajaran IPA.

Bagi guru, guru hendaknya menggunakan model problem based learning berbantu media audio visual karena dapat menjadikan guru lebih variatif dalam pembelajaran serta memudahkan guru dalam membangkitkan semangat siswa mengikuti pembelajaran IPA.

Bagi sekolah, disarankan kepada pihak sekolah khususnya Kepala Sekolah mengarahkan kepada guru-guru untuk menggunakan model problem based learning 
Efektivitas Model Problem Based Learning Berbantuan Media Audio Visual ditinjau dari Hasil Belajar IPA Siswa Kelas 5 SDN 1 Gadu Sambong - Blora (Adhini Virgiana Dan Wasitohadi)

berbantu media audio visual karena terbukti terdapat perbedaan tingkat efektivitas antara model problem based learning berbantu media audio visual dengan model pembelajaran think pair share berbantu media visual terhadap hasil belajar IPA siswa kelas 5 SDN 1 Gadu Sambong Kabupaten Blora semester 2 tahun pelajaran $2014 / 2015$.

\section{DAFTAR PUSTAKA}

Amir, M. Taufiq. 2009. Inovasi Pendidikan Melalui Problem Based Learning Bagaimana Pendidik Memberdayakan Pemelajar di Era Pengetahuan. Jakarta: Kencana.

Anitah, Sri. 2012. Media Pembelajaran. Surakarta: Yuma Pustaka.

Arends. 2008. Learning to Teach Belajar untuk Mengajar. Yogyakarta: Pustaka Pelajar.

Cahyo, Agus N. 2013. Panduan Aplikasi Teori-Teori Belajar Mengajar Teraktual dan Terpopuler. Yogyakarta: DIVA Press.

Darmansyah. 2006. Penelitian Tindakan Kelas. Padang: UNP.

Djamarah, dkk. 2006. Strategi Belajar Mengajar. Jakarta: PT. Rineka Cipta.

Lie, Anita. 2005. Cooperatif Learning: Mempraktikan Cooperatif Learning di Ruang-ruang Kelas. Jakarta: Gramedia.

Ngalimun. 2012. Strategi dan Model Pembelajaran. Yogyakarta: Aswaja Pressindo.

Nurkhikmah. 2013. Keefektifan Penerapan Model Problem Based Learning (PBL) Terhadap Peningkatan Kualitas Pembelajaran IPA. Journal of Elementary Education. 2 (2): 19-24.

Permendiknas Republik Indonesia No 22 Tahun 2006. Tentang Standar Isi Untuk Satuan Pendidikan Dasar dan Menengah. Jakarta: Debdikbud.

Permendiknas Republik Indonesia No 41 Tahun 2007. Tentang Standar Proses Untuk Satuan Pendidikan Dasar dan Menengah. Jakarta: Debdikbud.

Prametasari, Merinda Dian. 2012. Efektivitas Penggunaan Model Pembelajaran Berbasis Masalah (Problem Based Learning) Terhadap Hasil Belajar IPA Siswa Kelas V Di SD Gugus Hasanudin Salatiga Semester II Tahun Ajaran 2011/2012. Skripsi. Salatiga: Program Studi Pendidikan Guru Sekolah Dasar Fakultas Keguruan dan Ilmu Pendidikan Universitas Kristen Satya Wacana.

Priyatno, Duwi. 2010. Paham Analisis Statistik Data Dengan SPSS. Yogyakarta: Media Kom.

Sanjaya, Wina. 2007. Strategi Pembelajaran Berorientasi Standar Proses Pendidikan. Jakarta: Kencana Prenada Media Group. 
Sugiyono. 2011. Metode Penelitian Pendidikan (Pendekatan Kuantitatif, Kualitatif, dan $R \& D$ ). Bandung: ALFABETA.

Sugiyono. 2012. Metodologi Penelitian Kuantitatif Kualitatif dan R\&D. Bandung: ALFABETA

Suprijono, Agus. 2009. Model-Model Pembelajaran Inovatif Berorientasi Konstruktivistik. Jakarta: Prestasi Pustaka Publisher.

Sutikno, Sobry. 2009. Belajar dan Pembelajaran. Bandung: Cetakan Kelima.

Suyatno. 2009. Menjelajah Pembelajaran Inovatif. Surabaya: Masmedia Buana Pustaka.

Trianto. 2010. Mendesain Model Pembelajaran Inovatif-Progresif. Jakarta: Kencana Prenada Media Group.

Undang-undang Nomor 20 Tahun 2003 tentang SISDIKNAS. 2003. Jakarta: Debdikbud. 